\title{
ミリ波加熱を利用した不揮発性メモリー用強誘電体薄膜のアニーリング
}

\author{
松本 武, 三宅 正司
}

大阪大学接合科学研究所, $=567-0047$ 茨木市美穗ヶ丘 11-1.

\section{Annealing of Ferroelectric Thin Films for Non-volatile Memories by Millimeter-wave Heating}

\author{
Takeshi Matsumoto and Shoji Miyake \\ Joining and Whelding Research Institute, Osaka University, 11-1 Mihogaoka, Ibaraki 567-0047.
}

Received July 12, 2002

\begin{abstract}
SYNOPSIS
$\mathrm{SrBi}_{2} \mathrm{Ta}_{2} \mathrm{O}_{9}$ (SBT) films were prepared on $\mathrm{Pt} / \mathrm{Ti} / \mathrm{SiO}_{2} / \mathrm{Si}$ substrates by the spin-coating technique, and they were annealed by $28 \mathrm{GHz}$ millimeter-wave heating method. It was revealed that the annealed films were crystallized at a lower temperature than those by conventional electric furnace heating. For clarifying the difference in the interaction of the radiation with each materials of the substrate, transmission, reflection and absorption properties of various silicon substrates were measured by a low power millimeter-wave radiation. It was found that the carrier density of substrates exceedingly influenced millimeter-wave absorption. In the case of a low carrier density, the substrates were almost transparent for the millimeter-wave, while in the case of a high carrier density the reflection was dominant. KEY WORDS

SBT, millimeter-wave heating, crystallization, non-volatile memory
\end{abstract}

\section{1 緒 言}

近年，物質を加熱するための全く新しいエネルギー源とし てミリ波加熱が注目を集めている ${ }^{1,2)}$.この原理は電子レンジ として我々の身近に利用されているものであるが，これを工 業的に利用することにより，従来の電気炉加熱法等では実現 できない優れた特性を持つ材料を合成しようとする研究が盛 んにおこなわれている.ミリ波加熱法は(1)セラミックスなど の誘電体材料やその複合体を物質内部から加熱することがで きる. (2)物質の誘電損率の差異を利用した選択加熱ができる などの特徵を持ち、これを焼結に適用した場合には(3従来法 と比較して低温かつ短時間で維密化できるという特長がある.

以上のような特徵を持つミリ波加熱により高い曲け強度を 持つアルミナ焼結体の合成 ${ }^{3)}$, 高熱伝導性空化アルミニウムの 焼結 ${ }^{4}$, 高勒性窒化珪素の低温焼結 ${ }^{5)}$ など多数の成果が報告さ れているが，半導体の分野での研究報告はほとんどない。わ れわれは半導体分野でミリ波加熱の利用を進めてゆくことを 目論でおり，すでにペロブスカイト型誘電体薄膜の改良に大 きな成果を得ている ${ }^{6.7)}$. 本研究ではその一環として, Si 基板 および基板上に成膜した電極や誘電体薄膜のミリ波吸収特性 について調べ，ミリ波とこれらの物質の相互作用を明らかに
することを試みた．さらにその応用として, 強誘電体不揮発 性メモリー(FeRAM: Ferroelectric Random Access Memory)用材 料として注目されている $\mathrm{SrBi}_{2} \mathrm{Ta}_{2} \mathrm{O}_{9}(\mathrm{SBT})$ 薄膜をスピンコート 法により作製し，そのアニールプロセスにミリ波加熱を利用 して膜特性に与える影響を調べた。

FeRAMはフラッシュメモリーなど従来の不揮発性メモリー と比較して, 高速動作・低消費電力・低電圧駆動が可能であ るなどの魅力的な特長を有している.FeRAMに用いられる強 誘電体薄膜材料としてはまずPZTが挙げられるが, 電極材料 として Pt を用いた場合， $10^{8}$ 回程度の分極反転の繰り返しに よっていわゆる膜の疲労が生じ, その残留分極量が減少する という問題点がある.これに对し，SBTは1012回にわたる分 極反転の繰り返し後にも膜の疲労が見られないうえ，PZTよ りも抗電界が小さく，より低電死で駆動させることが可能で あるなどの特長を持つ.しかし，SBT は成膜後に行なわれる 結晶化アニールの温度が $800^{\circ} \mathrm{C}$ 程度とPZTの場合と比較して 高温であるため, Si 基板上の他のデバイス構成要素を破壊し てしまうという問題がある.

低温で結晶質 SBT を得るための手段として, SBTの成膜に ECR-MOCVD (Electron Cyclotron Resonance Plasma-Enhanced 
Metalorganic Chemical Vapor Deposition)を用いる方法 ${ }^{8)}$ や PLD (Pulsed Laser Deposition) を用いる方法"), あるいは結晶化ア ニールにレーザー照射 ${ }^{(0)}$ を用いる方法, さらにはスピンコー ト法でSBTを成膜する際に 1 回当たりの成膜厚さを薄くした うえに結晶化アニールに RTA (Rapid Thermal Annealing) 処理 を用いる方法 ${ }^{11}$ などが提案されている．本研究では結晶化ア ニールに上述のミリ波加熱を用い, SBTの結晶化温度の低温 化を試みるとともに，その特性を電気炉でアニールしたもの と比較した。

\section{2 実験方法}

$2.1 \mathrm{Si}$ 基板のミリ波吸収特性

Fig.1に示すようなミリ波帯準光学測定系を構築し, 試料の ミリ波透過率 $t$ および反射率 $r$ を測定した.ミリ波発振器は周 波数 $35 \mathrm{GHz} \sim 54 \mathrm{GHz}$ の電磁波を放射することができる. 反 射率を求める際には表面研磨したアルミニウムをミリ波の完 全反射体 $(r=1)$ と仮定し，その反射強度を基準として試料の 反射率を求めた。すなわち,

\section{$r=($ 試料からの反射信号強度)}

$$
\text { /(アルミニウムからの反射信号強度) }
$$

とした。また， $t, r$ を用いて吸収率 $a$ を，

$$
a=1-t-r
$$

\section{により算出した.}

被測定試料として, (1)ドーパントなしの Si(100) 基板(厚さ $1000 \mu \mathrm{m}$ ), (2) B ドープ p 型 Si $(100)$ 基板 (厚さ $500 \mu \mathrm{m}$, 比抵抗 $0.005 \Omega \mathrm{m}$ ), (3) B ドープ $\mathrm{p}$ 型 $\mathrm{Si}(100$ ) 基板 (厚さ $625 \mu \mathrm{m}$, 比抵抗

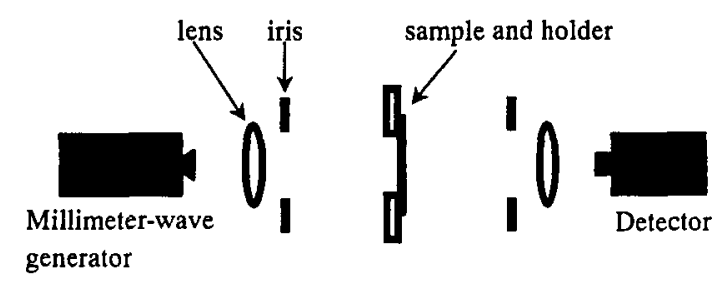

(a) Transmission

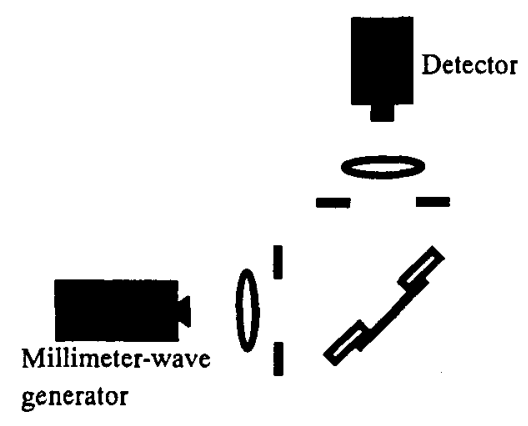

(b) Reflection

Fig.1 Schematic illustrations of systems for measuring millimeterwave transmission and reflection properties.
$0.1 \Omega \mathrm{m})$, (4) $\mathrm{Pt}$ 下部電極を(3)の $\mathrm{Si}$ 基板上に成膜したもの $(\mathrm{Pt}$ $\left.(100 \mathrm{~nm}) / \mathrm{Ti}(50 \mathrm{~nm}) / \mathrm{SiO}_{2}(650 \mathrm{~nm}) / \mathrm{Si}\right)$, および(5)バルク SBT (厚さ $2 \mathrm{~mm})$ を用いた。

2.2 SBT 薄膜合成・評価

基板として上記(1)のP 型 $\mathrm{Si}(100)$ (比抵抗 $0.1 \Omega \mathrm{m}$ ) を用いた. これを電気炉で加熱することによって表面酸化膜 (厚さ約 $650 \mathrm{~nm})$ を形成したのち, その上にイオンビームスパッタリン グ法により $\mathrm{Ti}$ ( 厚さ約 $50 \mathrm{~nm}$ ), さらに $\mathrm{Pt}$ (厚さ約 $100 \mathrm{~nm}$ )を成 膜した.こうして得られた $\mathrm{Pt} / \mathrm{Ti} / \mathrm{SiO}_{2} / \mathrm{Si}$ 基板上にスピンコート 法によりSBT 薄膜を作製した。前駆体溶液 (関東化学株式会 社製 ) には Sr : Bi : Ta=0.8:2.2:2.0の組成のものを用いた. 成 膜条件は回転速度 $3000 \mathrm{rpm}$, 回転時間 $45 \mathrm{sec}$. である. その後,

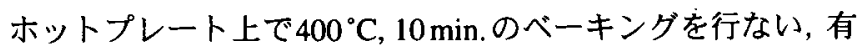
機物を除去した. 上記のコーティング・ベーキングを 5 回繰 り返し，厚さ約 $210 \mathrm{~nm}$ のSBT薄膜を作製した．この薄膜を電 気炉加熱および周波数 $28 \mathrm{GHz}$ のミリ波加熱により酸素雲囲気 中で所定の温度に $30 \mathrm{~min}$. 保持し, 結晶化の様子を調べた.

結晶相の同定には $\mathrm{Cu}-\mathrm{K} \alpha$ 線を利用した $\theta$ 固定法(固定角 $2^{\circ}$ ) のXRD 装置 (株式会社マックサイエンス製)，断面観察には SEM (日本電子株式会社製)，膜厚測定には段差膜厚計 (Dektak)を用いた。

\section{3 実験結果と考察}

$3.1 \mathrm{Si}$ 基板のミリ波吸収特性

Fig.2に各種基板のミリ波透過・反射・吸収特性を示す。こ れによるとドーピングなしの純粋な $\mathrm{Si}$ の場合にはミリ波は吸 収・反射されることなしにほとんど透過してしまうが，これ にボロンをドープすることによって透過強度が著しく減少す ることが分かる.これは Si 基板中のキャリアーとミリ波の相 互作用が大きいことを示唆している. また，比抵抗が減少す るにともない, すなわちキャリアー濃度が増加するにともな い, 次第に反射強度が増加し, 透過強度が減少する. さらに, 比抵抗0.1 $\mathrm{\Omega m}$ のSi基板の場合にはある程度の透過が存在して いるのに対し，キャリアー濃度が最も高い比抵抗 $0.005 \Omega \mathrm{m} の$ $\mathrm{Si}$ 基板の場合にはミリ波の大部分は $\mathrm{Si}$ 基板表面で金属的に反 射され，残りは吸収されるために全く透過しないことが分か る.この事実は表皮効果の式,

$$
\delta=\sqrt{\frac{2}{\mu_{0} \sigma \omega}}
$$

によって検討を加えることができる.ここで只は真空の透磁 率, $\sigma$ は基板の導電率, $\omega$ はミリ波の振動数である.この式を 用いてミリ波浸透哚さを算出すると, 比抵抗 $0.005 \Omega \mathrm{m} の \mathrm{Si}$ 基 板の場合には $40 \mu \mathrm{m}$ 程度であるのに対し，比抵抗 $0.1 \Omega \mathrm{m}$ の Si 基板の場合には $750 \mu \mathrm{m}$ 程度という結果が得られる.このよう に比抵抗が小さい基板は表面でミリ波を反射するため, 吸収 に寄与できる領域が基板のごく表面のみに限定され, 結果的 にエネルギーを吸収しにくくなる.この結果はH. Zohm らの 結果 ${ }^{12)}$ と定性的に一致している. 


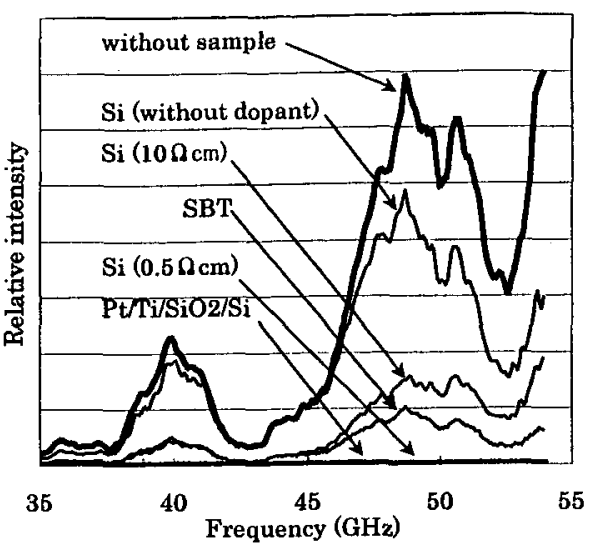

(a) transmission

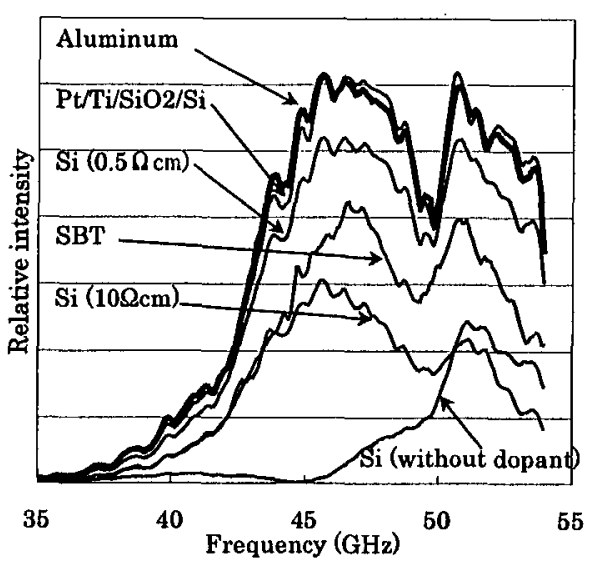

(b) reflection

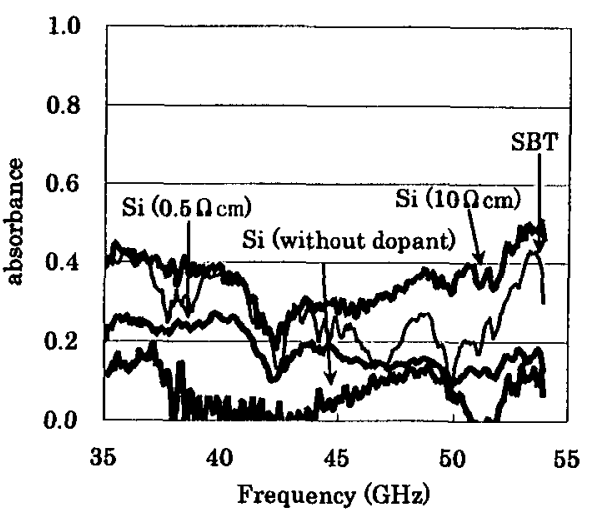

(c) absorbance

Fig.2 Transmission, reflection and absorption properties for various substrates as a function of irradiated millimeter-wave frequency.

以上をまとめると, キャリアー濃度が低すぎるとミリ波の 大部分は基板を透過してしまうためにエネルギーを吸収でき ず，逆にキャリアー濃度が高すぎても基板表面で反射される ために吸収できないということになる．したがって，ミリ波 の吸収効率はキャリアー濃度に対して極大值をもつものと考 えられ，実験結果も同様の傾向を示している. キャリアー濃 度が高くなるとミリ波を反射するという事実から，このよう なシリコンのミリ波吸収メカニズムは金属の誘導加熱と同様 であると推测でき，ミリ波によってシリコン内部に誘起され る電流が引き起こすジュール加熱が吸収の主原因であるとの 結論が導き出される.

つぎに, $\mathrm{Pt} / \mathrm{Ti} / \mathrm{SiO}_{2} / \mathrm{Si}$ 基板についても同様の測定をおこなつ たところ, 表面のPt/Tiによってミリ波の大部分が反射されて しまうためにほとんど透過・吸収しないという結果を示した. これによりわずか数百 $\mathrm{nm}$ 金属膜でもミリ波を完全に反射す るのには十分であることが明らかとなった。

さらにSBTのミリ波吸収を調べるためにバルクSBTについ ても測定をおこなった. Fig.2に示したSBTの結果はランベル ト・ベールの式を用いて厚さ $625 \mu \mathrm{m}$ の值に值したものであ る.この図から，SBTのミリ波吸収は今回測定した 2 種類の Bドープ基板とほほ同等であることがわかる.したがって, Si 基板上のSBT薄膜をミリ波によって加熱した場合, SBTは自 己が加熱されるとともに基板からの熱伝達によっても加熱さ れるということが推測される.

今回, 各種基板のミリ波吸収特性を計测した周波数帯域は, 本研究でおこなったSBT薄膜のミリ波加熱に用いた周波数で ある $28 \mathrm{GHz}$ を含んでいない.しかし，Fig.2(c)で吸収に顕著な 周波数依存性が見られないうえ，ミリ波吸収特性計測に使用 した電磁波の波長と, SBT薄膜のミリ波加熱に用いた電磁波の 波長は両者ともに基板および薄膜の厚みと比較して十分に長い ので, 上記の考察はSBT薄膜のミリ波加熱に使用した周波数 $28 \mathrm{GHz}$ の電磁波に対しても同様に成り立つものと推論できる. 本研究ではミリ波加熱によってSBT薄膜のアニーリングを
おこなう際，試料はアルミナ製の試料台の上に設置した．そ のときのSBT薄膜試料と試料台の温度を計測した結果, 試料 台の温度は試料温度と比較して十分に低いことが確認された。 このことから，本研究における試料の加熱様式は試料台から の熱伝達により加熱される外部加熱式ではなく, 試料そのも のが加熱される内部加熱式であることが明らかとなった. $\mathrm{SBT}$ 成膜の際に用いた比抵抗 $0.1 \Omega \mathrm{m}$ の $\mathrm{Si}$ 基板のミリ波吸収が 比較的大きいという Fig.2の結果と併せて考えると, SBT薄膜 のアニーリング時にミリ波は試料台よりもSi基板の方により 強く吸収されるということを示しているものと結論できる。

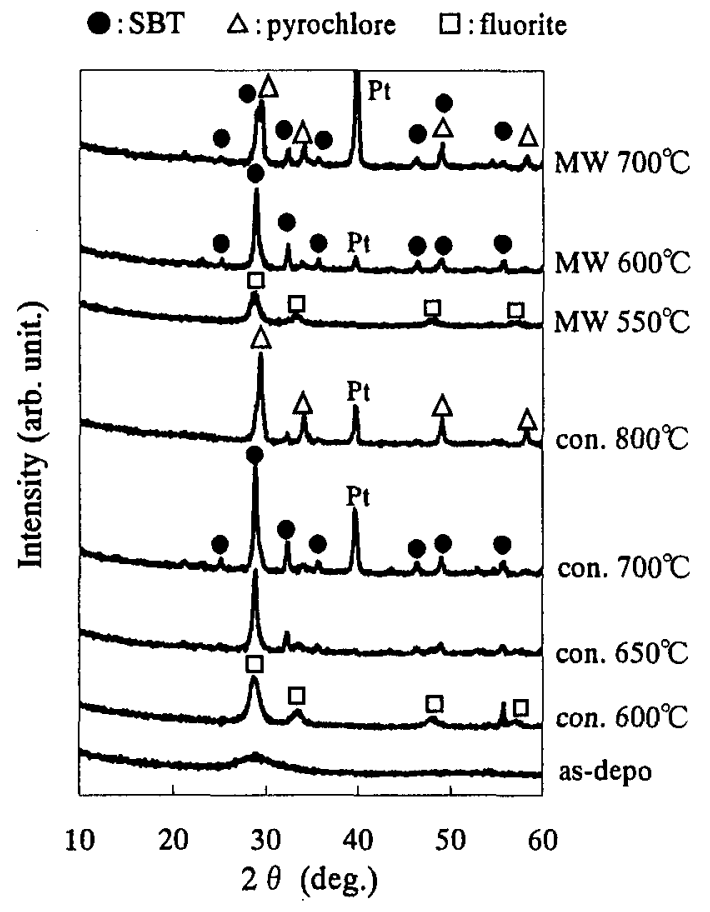

Fig.3 X-ray diffraction patterns of SBT films annealed by conventional furnace (con.) and millimeter-wave heating (MW). 


\subsection{SBT 薄膜合成・評価}

電気炉および周波数 $28 \mathrm{GHz}$ のリ波加熱をもちいてアニー リングをおこなつたSBT試料のXRDパターンをFig.3に示す. アニーリング前の段階ではアモルファスだったSBT膜が電気 炉の場合は $650^{\circ} \mathrm{C}$ 以上で, ミリ波加熱の場合は $600^{\circ} \mathrm{C}$ 以上で SBT 相に結晶化することがわかった．このようにミリ波加熱 は薄膜の結晶化温度の低温化に有効であるが, このような事 実は馬場らによっても報告されている7). 焼結の分野では, ミ リ波が物質中に形成する電場が拡散の付加的な駆動力なるた めに低温での焼結が可能になると説明されており，本研究の 場合にも同様の機構が作用しているのではないかと推測され る. また, アニーリング温度を上昇させた電気炉 $800^{\circ} \mathrm{C}$ の場
合にはパイロクロア相が確認された．このパイロクロア相は Rodriguezらによると $\mathrm{Sr}_{0.2}\left(\mathrm{Sr}_{0.5} \mathrm{Bi}_{0.7}\right) \mathrm{Ta}_{2} \mathrm{O}_{6.75}$ の組成であるとされ ており ${ }^{13)}, \mathrm{Bi}$ 欠乏時に見られる相である.この相が生じたの は高温でアニールすることにより Biが揮発し, Bi不足が生じ たことに原因があるものと考えられる. 本研究で用いた前駆 体溶液の組成はBi 過剩組成であるが, 揮発量がその過剩量よ りも多かったためにBi不足になったものと思われる. パイロ クロア相がSBT相よりも優勢になる温度は電気炉加熱の場合

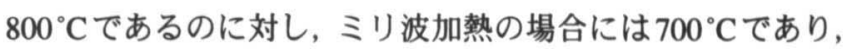
この点においてもミリ波の非熱的効果の存在が示唆される.

つぎに Fig.4に試料表面のSEM写真を示す. 電気炉加熱 $650^{\circ} \mathrm{C}$ およびミリ波加熱 $600^{\circ} \mathrm{C}$ の試料において針状の結晶粒の存在

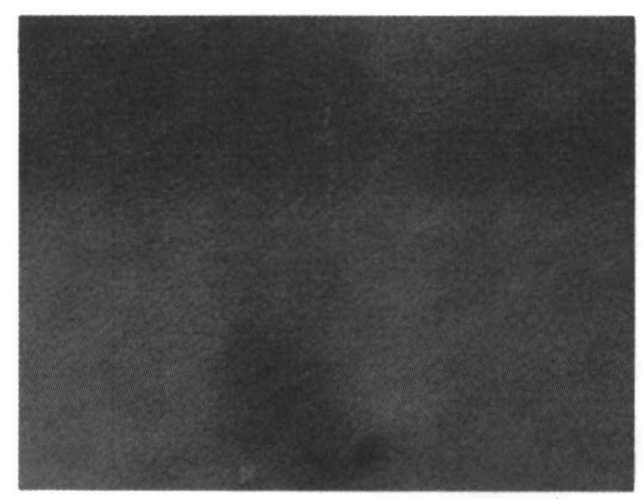

(a) as-depo.

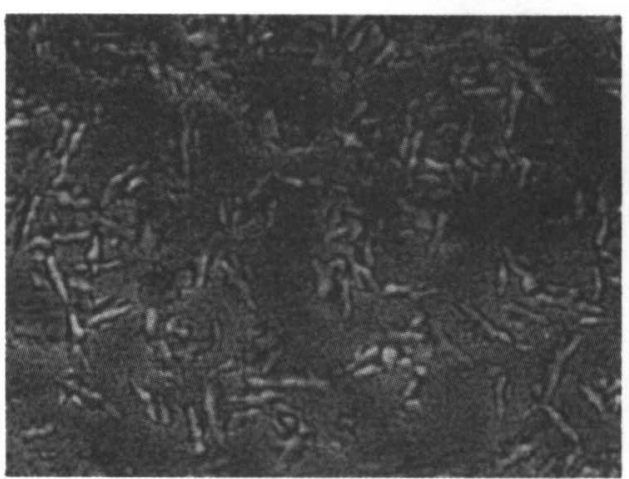

(c) con. $650^{\circ} \mathrm{C}$

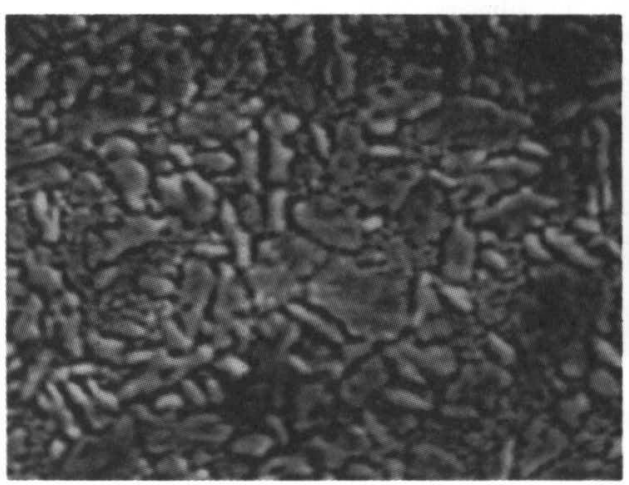

(e) con. $700^{\circ} \mathrm{C}$

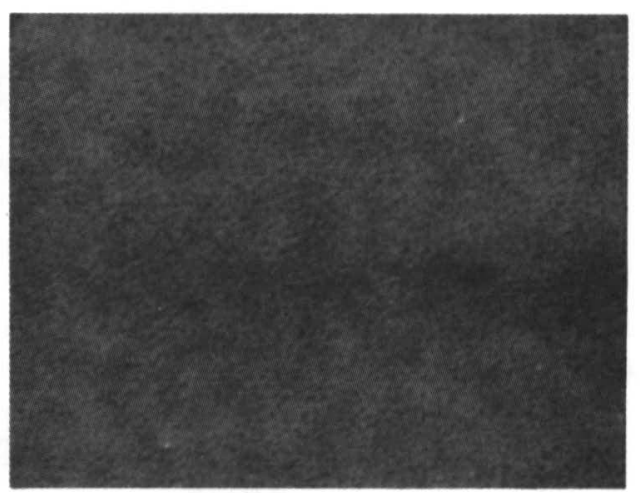

(b) con. $600^{\circ} \mathrm{C}$

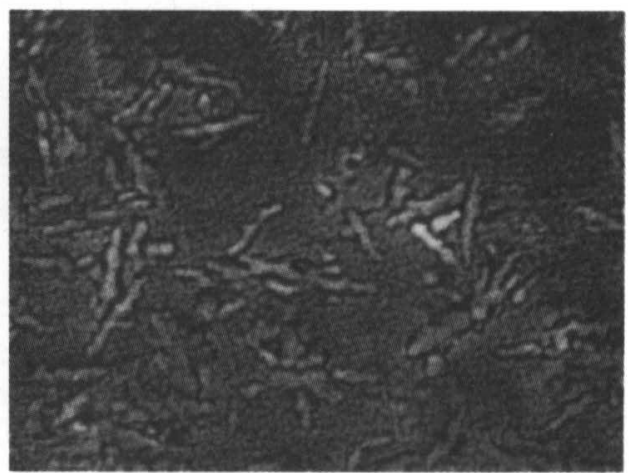

(d) $\mathrm{MW} 600^{\circ} \mathrm{C}$

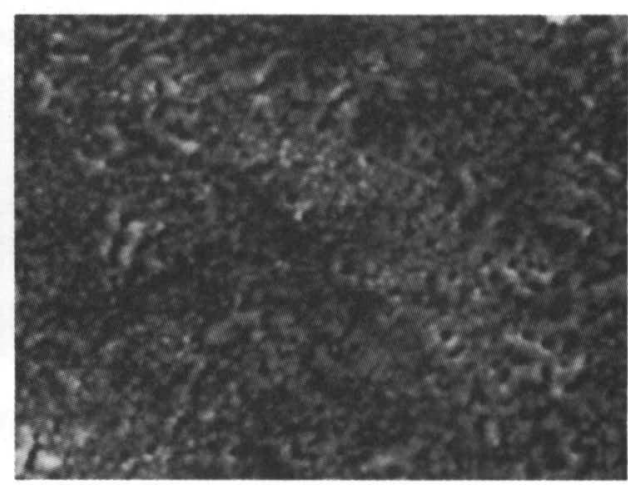

(f) con. $800^{\circ} \mathrm{C}$

$1 \mu \mathrm{m}$

Fig.4 SEM photographs of SBT films annealed by conventional furnace (con.) and millimeter-wave heating (MW). 
を確認できた．両者の結晶粒の大きさを比較するとミり波加 熱の場合の方が大きい，XRDの結果からこれら温度以上で SBT相への結晶化が確認されているので, この結晶粒はSBT 相であると考えられる. しかし，この温度では結晶粒が見ら れない部分も残っているため, 完全にSBT相に結晶化させる ためにはより高温でのアニールが必要であると結論できる. これに対して, 電気炉加熱 $700^{\circ} \mathrm{C}$ の試料のSEM写真では全面 に結晶粒が確認でき，試料全体がSBT相へ結晶化しているも のと考えられる.さらに高温の電気炉加熱 $800^{\circ} \mathrm{C} の \mathrm{SEM}$ 写真 では起伏が見られるうえに，モルフォロジーが $700^{\circ} \mathrm{C}$ の場合 と異なっており，細かい粒状の結晶が見られる．これとほぼ 同様のモルフォロジーがP. Tejedorらのおこなったパイロクロ ア相を含む膜の AFM 観察によっても報告されており ${ }^{14)}$, パイ ロクロア相の析出によってモルフォロジーが変化したものと 考えられる. 細かい粒状の結晶がパイロクロア相，わずかに 見られる針状の結晶がSBT 相であると推測される.

\section{4 まとめ}

ミリ波帯の電磁波に関して, Si 基板および Pt 電極の透過・ 反射・吸收特性を測定した結果, 以下の事実が明らかとなった。

(1) $\mathrm{Si}$ 基板のミリ波吸収は $\mathrm{Si}$ 基板中のキャリアーが主たる原 因で発生する.キャリアーなしの場合にはミリ波をほとん ど吸収・反射せず透過するのに対し，キャリアーが増加す るにつれて金属的性格が增し，反射が強くなるとともに透 過しなくなってゆく，吸収は反射・透過との兼ね合いに よって決まるので, 適当なキャリアー濃度のときにもっと も効率的にミリ波を吸収する。

（2）Si 基板上の SBT 薄膜をミリ波加熱した場合，SBT は自己 が加熱されるとともに基板からの熱伀達によっても加熱さ れる。

(3) $\mathrm{Pt}(100 \mathrm{~nm}) / \mathrm{Ti}(50 \mathrm{~nm}) / \mathrm{SiO}_{2} / \mathrm{Si}$ 基板はミリ波をほぼ完全に反射 する. わずか $150 \mathrm{~nm}$ の金属膜でもミリ波を反射するのに 充分な厚さである.

また，ミリ波加熱によりアニーリングをおこなった SBT 膜 を従来の電気炉によってアニーリングしたものと比較した結 果, 以下の事実が明らかとなった.

(1) SBT相への結晶化が開始するアニーリング温度は電気炬加 熱の場合は $650^{\circ} \mathrm{C}$ であるのに対し，ミリ波加熱の場合は $600^{\circ} \mathrm{C}$ であった. ミリ波加熱のもつ非熱的効果の存在が示 唆される.

(2) 高温でアニーリングすることによって Bi 欠損が生じ，パ イロクロア相が析出する. パイロクロア相が SBT 相より も優勢になる温度は電気炉加熱の場合には $800^{\circ} \mathrm{C}$ C゙あるの に対し、ミリ波加熱の場合には $700^{\circ} \mathrm{C}$ であった.

\section{文献}

1) W.H.Sutton: "Microwave processing of ceramics -an overview", Mater. Res. Soc. Symp. Proc., 269(1992)3-20.
2) 三宅正司: ニューセラミックス, 10(1997)1-7.

3) Y.Makino, S.Miyake, S.Sano, H.Saito, B.Kyoh, H.Kuwahara and A. Yoshikawa: "Millimeter-Wave Sintering of High Pure Alumina and Structural and Mechanical Properties", $8^{\text {th }}$ International Conference on Microwave and High Frequency Heating, Bayreuth, Germany, Sept., (2001) 149-151.

4) T.Yoshioka, Y.Makino and S.Miyake: "Low temperature sintering of aluminum nitride with millimeter-wave heating", J. Mater. Sci., (in press).

5) T.Ueno, H.Saito, S.Sano, Y.Makino and S.Miyake: "Rapid fabrication of new silicon nitride containing $\mathrm{Yb}_{2} \mathrm{O}_{3}-\mathrm{Al}_{2} \mathrm{O}_{3}$ additives with $28 \mathrm{GHz}$ millimeter-wave heating", Powder Metallurgy World Congress 2000, Kyoto, Japan, Nov., (2000) 753-756.

6) 新納厚志, 松本武, 三宅正司: "ECR スパッタリングによ る高誘電率セラミックス薄膜の結晶性に対するミリ波効 果 (II)", 粉体粉末冶金協会講演概要集, 東京, (2002) 186 .

7) S.Baba, K.Numata, H.Saito, M.Kumagai, T.Ueno, B.Kyoh and S.Miyake: "Preparation of Strontium Titanate Thin Films by Mirror-Confinement-Type Electron-Cyclotron-Resonance Plasma Sputtering", Thin Solid Films, 390(2001)70-75.

8) N.Nukaga, M.Mitsuya and H.Funakubo: "Low-Temperature Preparation of $\mathrm{SrBi}_{2} \mathrm{Ta}_{2} \mathrm{O}_{9}$ Thin Films by Electron Cyclotron Resonance Plasma-Enhanced Metalorganic Chemical Vapor Deposition", Jpn. J. Appl. Phys., 39(2000)5496-5500.

9) M.Noda, Y.Adachi, H.Sugiyama.T.Nakaiso and M.Okuyama: "Low-temperature preparation of $\mathrm{Sr}_{\mathbf{x}} \mathrm{Bi}_{2+y} \mathrm{Ta}_{2} \mathrm{O}_{9}$ ferroelectric thin film by pulsed laser deposition and its application to a metalferroelectric-nitride-oxide-semiconductor structure", Appl. Phys., A71(2000)113-116.

10) T.Zhu, Y.P.Wang, L.Zhou and Z.G.Liu: "Properties of SBT films crystallized by pulsed eximer $(\mathrm{KrF})$ laser annealing", Materials Science and Engineering, B89(2002)390-393.

11) G.D.Hu, I.H.Wilson, J.B.Xu, C.P.Li and S.P.Wong: "Lowtemperature preparation and characterization of $\mathrm{SrBi}_{2} \mathrm{Ta}_{2} \mathrm{O}_{9}$ thin films on (100)-oriented $\mathrm{LaNiO}_{3}$ electrodes", Appl. Phys. Lett., 76(2000) 1758-1760.

12) H.Zohm, E.Kasper, P.Mehringer and G.A.Müller: "Thermal processing of silicon wafers with microwave co-heating", Microelectronic Engineering, 54(2000)247-253.

13) M.A.Rodriguez, T.J.Boyle, B.A.Hernandez, C.D.Buchheit and M.O.Eatough: "Formation of $\mathrm{SrBi}_{2} \mathrm{Ta}_{2} \mathrm{O}_{9}$ : PartIl. Evidence of a bismuth-deficient pyrochlore phase", J. Mater. Res., 11(1996) 2282-2287.

14) P.Tejedor, C.Ocal, E.Barrena, R.Jiménez, C.Alemany and J.Mendiola: "Composition-related effects of microstructure on the ferroelectric behavior of SBT thin films", Appl. Surface Sci., 175(2001)759-763. 